\title{
Identifying potential RNAi targets in aphid species (Macrosiphum rosae, Rhopalosiphum maidis, Sitobion avenae, Toxoptera aurantii) in sub-tropical region with extreme summer
}

\author{
Amber Afroz*, Maria Hashmi, Umer Rashid, Nadia Zeeshan \\ Department of Biochemistry and Molecular Biology, Nawaz Sharif Medical College, University of Gujrat, Hafiz \\ Hayat Campus Gujrat, Gujrat, Pakistan
}

*Corresponding author: dramber.afroz@uog.edu.pk; ambernics01@gmail.com

\begin{abstract}
RNA interference is a useful and efficient tool that had been used to incorporate tolerance against different stresses. Five unigene sequences were selected from exotic grain aphid that were reported to be an ideal RNAi targets. Aphids (Macrosiphum rosae, Rhopalosiphum maidis, Sitobion avenae, Toxoptera aurantii) were reared on Rosa indica, Zea mays, Triticum aestivum, Chrysanthemum hibiscus, Solanum melongena, Abelmoschus esculentus. PCR of unigene 28469 and 21789 was positive for all aphids and there is no ortholog found for them so unique and effective to be used in RNAi technology. Cytochrome c oxidase was found to be positive for $M$. rosae, S. avenae, T. aurantii and negative for $R$. maidis. Zinc finger protein was found to be positive for R. maidis, S. avenae and negative for M. rosae, and T. aurantii. Cuticular proteins was found to be positive for $S$. avenae and M. rosae and negative for $R$. maidis and $T$. aurantii. Genes identified in the aphids are defense and as important structural genes and their suppression with RNAi technology will be important target to have insect resistant crops. From these gene sequences cytochrome c oxidase is reported as bar coding gene and can be used in future for interspecific genetic variation in these aphids. Results revealed the high expression of these sequences in local aphid species and can be used as RNAi target for them. That can be used in future or applications as pest management, monitoring and plant quarantine.
\end{abstract}

Keywords: Aphids, Sitobion avenae, RNA interference, Cytochrome c oxidase.

Abbreviations: RNA interference (RNAi); Bacillus thuringiensis (Bt); Double stranded RNA (dsRNA); messenger RNA (mRNA); RNA-dependent RNA polymerase (RdRP); Cytochrome c oxidase (CO-1); Cuticular proteins (CPs).

\section{Introduction}

Aphids are chief agricultural pests, plays an important role in the destruction of crops including cereals, oilseeds, timber and fruit and important medical plants all over the world through the direct effects of feeding and by vectoring debilitating plant viruses (Dedryver et al., 2010; Bhatia et al., 2011). Annual worldwide crop losses due to aphids are estimated at hundreds of millions dollars (Blackman and Eastop, 2000; 2006, Oerke et al.,1994). 11 subfamilies and 4,400 species of aphids, which are known all belongs to the family aphidoidea, and among them 250 species are serious pests and causes yield loss (Blackman and Eastop, 2006). One of the important species infesting wheat is grain aphid, most dominant and destructive, affecting $65 \%$ of wheat production areas in China, Europe and America (Stoger et al., 1999; Zhang et al., 2009). Small amount of data is available for the Homoptera order of aphids Diuraphis noxia, Schizaphis graminum and Rhopalosiphum padi affecting wheat crops in hot tropical areas of Punjab (Muhammad et al., 2013; Khan et al., 2012; Aslam et al., 2004; Shahzad et al., 2013). Selection of the RNAi targets for grain aphid is constraint because of lack of genomic information and small alimentary canal (Xu et al., 2014). Agrochemical insecticides are intimidated by development of insecticide resistance, human health, environmental hazards, non-specificity, and toxicity (Usta, 2013). Therefore, targeted alternative is the need of the hour. For the last few decades, conventional breeding programs have been undertaken in an attempt to increase wheat aphid resistance worldwide (Stoger et al., 1999). However, due to the lack of effective aphid resistant germplasm, the complexity of plant-aphid interactions and the rapid development of resistant pest biotypes, occurrence of aphids causing substantial losses of wheat continue to be reported regularly. Breeders and growers are still struggling to find an efficient genetic strategy for aphid control in wheat (Yu et al., 2012).

Transgenic crops are an option for insecticidal proteins production for e. g lectin and protease inhibitor (Wang et al., 2005; Hossain et al., 2006; Rahbe et al., 2003). Characterization and expression study of chitin-binding lectin, was associated with resistance against Hessian fly and grain aphid (Giovanini et al., 2007; Repellin et al., 2001). Altpeter et al. (1999) introduced barley trypsin inhibitor into wheat against grain moth (Sitotroga ceralella) a major pest of stored wheat grain. Li et al. (2014) reported the harpin protein (Hpa1) with manifold effects in wheat, promoting plant growth with increased crop yield, and inducing resistance to insects. In related study wheat was genetically modified to release insect pheromone (farnesene synthase) for defense (Bruce et al., 2015). Bacillus thuringiensis (Bt) toxin as a pesticide replaced use of chemical insecticides on range of crops and Bt resistant crops had been developed as well. However, Bt toxins, is found to be not efficient for 
chewing-type insects, and development of resistance against toxins had been reported (Mao et al., 2007).

RNA interference (RNAi) is important phenomenon playing vital role as reverse genetics to study gene function. RNAi was described as post transcriptional gene silencing; done by transmitting single stranded RNA or double stranded RNA (dsRNA) for silencing toxin receptors, pigment or target genes (Kumar et al., 2009; Zha et al., 2011). With RNAi method dsRNA lowers transcript abundance of target gene when injected in organism, cultured cells or feeding on artificial diet containing dsRNA (Shakesby et al., 2009; Fire et al., 1998). Down regulation of targeted genes by using plants mediated RNAi was thru (Pitino and Hogenhout, 2013). Digestive proteolytic activity of aphid nymphs mainly relies on enormous serine proteases. So, protease inhibitors induction in tissues is reported for production of immunity against Myzus persicae in Arabidopsis (Bhatia et al., 2012). RNAi involves cleavage of dsRNA into small interfering RNA of approximately 21-23 nucleotides by enzyme dicer (Meister and Tuschl, 2004). These siRNAs than incorporate into RNA-induced silencing complex. RISC catalytic contents use siRNA as template to recognize and degrade complementary messenger RNA (mRNA) (Meister and Tuschl, 2004). Host-mediated delivery of dsRNA is an attractive paradigm for developing aphid resistance inspite of elusive mechanistic details governing the uptake of dsRNA in aphids. Successful knockdown of target genes through RNAi was also observed in pea and peach aphid (Mutti et al., 2006; Whyard et al., 2009; Possamai et al., 2007; Shakesby et al., 2009; Pitino et al., 2011), however, systemic RNAi assay evidence was missing in aphid species. Orthologs of RNAdependent RNA polymerase (RdRP) are present in nematodes, plants and higher animals, the presence of RdRP was never confirmed in insects (Jose and Hunter, 2007; Tomoyasu et al., 2008; Richard et al., 2008). So, systemic RNAi probably does not exist in insects. Systemic RNAi twigs both cell-self signal and environmental RNAi signal in which: silencing signal is transported from the parent cell (dsRNA is applied) to other cells/ tissues (Huvenne and Smagghe, 2010). Gene knockdown effects exhibited by injecting and/or feeding dsRNA to insects was limited to cells that have taken up dsRNA (Price and Gatehouse, 2008; Zha et al., 2011). So, it will require continuous input of dsRNA to persist. Systemic RNAi has been demonstrated in some insect species, such as Hyalophora cecropia and Bombyx mori, in which injection of dsRNA into the larvae, demonstrating a persistence of the RNAi signal throughout the larval and adult stages and systemic spread of RNAi signal from the gut to the antennae (Terenius et al., 2011; Turner et al., 2006). Recently a comprehensive transcriptomic data analysis was done to find out all the unigenes expressed in grain aphid after wheat feeding. 30,427 novel unigenes were identified in grain aphids as successful target of RNAi after gene expression analysis of their alimentary canal. From all these unigenes, 5 were reported to favor minimal risk of non-specific target but also maintain the low efficacy of lethal dose in comparison to previous studies (Zhang et al., 2013; Pitino et al., 2011). These target genes after their confirmation and introduction in our local wheat varieties will be efficient for aphid control in local agricultural practice. Therefore, area of interest is

(a) To find out these unigene sequences causing RNAi assay in local species of aphids. (b) To find the expression of those genes by doing RTPCR analysis.

\section{Results}

RNAi is a useful and efficient generic tool that had been used in the field of insect functional genomics. This technology had been used for the screening of efficient and new insect resistance gene and to create crops having resistance against aphids. Aim of research was to explore most effective unigene sequences from samples collected from local weather environment, These 5 unigenes were reported to be efficient in causing mortality of grain aphid. Other than this there were 2-3 factors for the choice of these unigenes as RNAi targets. All the differentially expressed unigenes directly or indirectly involved in the activity of oxidationreduction processes like NADH dehydrogenase, oxidoreductase, so their suppression will be excellent approach for transgenic crop production especially wheat. Secondly artificial feed also because high mortality within 24 hours comparable to microinjection and low dosage of the construct in artificial diet was found to be efficient for aphid mortality. The 5 unigene sequences selected will be used for RNAi based assay by producing transgenic tobacco followed by transgenic corn and wheat (Zhang et al., 2013).

DNA extraction from aphids Macrosiphum rosae, Rhopalosiphum maidis, Sitobion avenae, Toxoptera aurantii reared on Rosa indica, Zea mays, Triticum aestivum, Chrysanthemum hibiscus, Solanum melongena, Abelmoschus esculentus was done (Fig 1).

DNA extraction was done using CTAB-PVP DNA extraction protocol with freshly collected preserved specimens in $70 \%$ ethanol, which didn't give satisfactory results. So phenol chloroform method was then used for the DNA extraction (Fig S1A). Both quality and quantity of extracted DNA was improved with this method. DNA extraction from old specimens might have been poor result due to degradation of DNA in the dead samples but, in our case we have good results in both fresh and preserved samples (Hajibabaei et al., 2006; Wang et al., 2013).

Incubation of sample with lysis buffer gives good quality pallet of DNA. Multiple Methods were used for the extraction of RNA from samples of aphids show positive results in aphids. Best results were obtained with the Trizol reagent extraction (Tri Reagent: Sigma-Aldrich. Product No. T9424). RNA extraction is done for checking the expression of 5 unigene sequences within our collected species, by running the sample on gel electrophoresis. A band with a little smear confirms the presence of RNA in sample (Fig S1B, S1C). CDNA was prepared from these RNA and utilized for PCR amplification. Positive results were shown from both set of extracted RNA from gut region and from whole aphids. (Fig S1D). To find presence of desire sequences five set of unigene primers were used (Table No 2). $T_{m}$ optimized for each primer is given in Table 2.

Presence of unigenes was confirmed in all five namely $(M$. rosae, $R$. maidis, S. avenae, T. aurantii reared on $R$. indica, $Z$. mays, $T$. aestivum, $C$. hibiscus, $S$. melongena, $A$. esculentus) at optimized conditions. Size of the DNA bands $(159 \mathrm{~kb})$ for all sequences was confirmed with $100 \mathrm{bp}$ ladder (Fig 2A, 2B, 2C \& Fig 3).

\section{Unigenes 21789 and 28469}

Unigenes 21789 and 28469 had no orthologues identified in aphids or wheat. PCR results were found to be positive with all four aphid strains e.g. M. rosae, $R$. maidis, $S$. avenae, $T$. aurantii with 211 bps and 257 bps respectively. (Fig 2A; Table 3). 
Table 1. Name of the Aphids collected from their respective host plant.

\begin{tabular}{ll}
\hline Aphid Species & Host plant \\
\hline Macrosiphum rosae & Rosa indica \\
Rhopalosiphum maidis & Chrysanthemum, Hibiscus rosa-sinensis, Solanum melongena, Abelmoschus esculentus \\
Sitobion avenae & Chrysanthemum, Hibiscus rosa-sinensis, Solanum melongena, Abelmoschus esculentus, Triticum aestivum \\
Toxoptera aurantii & Citrus sinensis \\
\hline
\end{tabular}

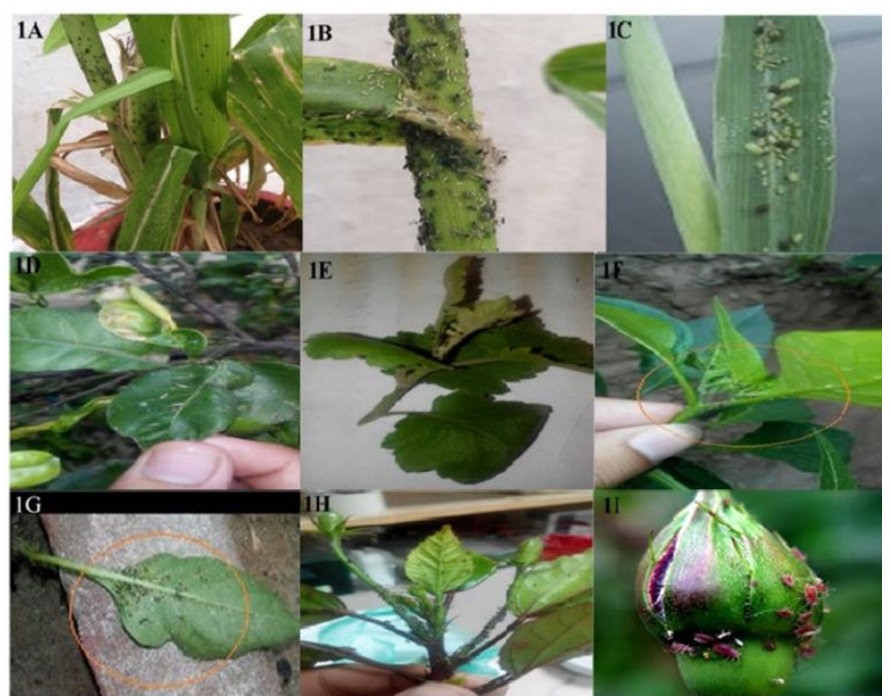

Fig 1. Sampling of Macrosiphum rosae, Rhopalosiphum maidis, Sitobion avenae, Toxoptera aurantii reared on Rosa indica, Zea mays, Triticum aestivum, Chrysanthemum hibiscus, Solanum melongena, Abelmoschus esculentus. (1A \& 1B) Samples of $R$. maidis on Z. mays. (1C) Samples of S. avenae on T. aestivum. (1D and 1E) Samples of T. aurantii on C. sinensis and Chrysanthemum (1F and $1 \mathrm{G}$ ) Samples of $S$. avenae on S. melongena \& C. annum. (1H) Samples of S. avenae on H. rosa-sinensis (1I) Samples of M. rosae on $R$. indica.

\section{Unigene 21088}

Unigene sequences 21088 showed positive PCR results with $M$. rosae, $T$. aurantii and $S$. avenae but no results were shown for R. maidis with 198 bps (Fig 3).

\section{Unigene 23028}

Unigene 23028 expressed positive PCR results with $R$. maidis, S. avenae but no results were showing with $M$. rosae and T. aurantii with 195 bps (Fig 2C).

\section{Unigene 8273}

Unigene 8273 give results with $M$. rosae and S. avenae no results were found with $R$. maidis and $T$. aurantii. Overall results from above mentioned reactions are presented (Table $3)$.

All 5 unigenes $(21789,28469,21088,23028 \& 8273)$ sequences were found in $S$. avenae isolated from $S$. melongena, $C$. annum, $T$. aestivum and $H$. rosa-sinensis, similar to unigenes isolated from $S$. avenae reared on wheat (Zhan et al., 2013). Unigene sequences were also found to be present in $S$. avenae isolated from chilies, brinjal, Gul-Lala and local wheat plants. While other aphids represent variable results (Fig 2B).

\section{Discussion}

In Pakistan other than wheat major staple crop, fruits, vegetables, brinjal, are main host of aphid causes 10-90\% damage to crops every year (Irshad, 2001). Severity of aphid infestation $70-80 \%$ loss in yield exceeded all over the world (Dedryver et al., 2010; Bhatia et al., 2011; Blackman and
Eastop, 2000; 2006). R. maidis, S. avenae, M. rosae and $T$. aurantii were reported to be important graminaceous, fruits, vegetable and rose aphids in northern areas and subtropical regions of Punjab, Pakistan (Hamid, 1983; Wains et al., 2014; Mani, 1987; Quratulain, 2015). D. noxia, S. graminum and $R$. padi are some other aphids affecting wheat crops in tropical areas of Punjab areas (Muhammad et al., 2013; Khan et al., 2012; Aslam et al., 2004; Shahzad et al., 2013; Faheem et al., 2015). RNAi technology is widely reported for pest control by knocking down vital insect genes. Among insect pests, aphids also respond to the successful delivery of siRNA or dsRNA by triggering RNAi responses (Mutti et al., 2006; Possamai et al., 2007). The cells of the insect gut lumen take up dsRNA either by oral delivery or through artificial diet or ingestion of bacteria expressing dsRNA (Turner et al., 2006; Huvenne and Smagghe, 2010; Tian et al., 2009). Although mechanistic details governing the uptake of dsRNA in aphids still remain elusive, host-mediated delivery of dsRNA is still an attractive paradigm for developing aphid resistance. Transgenics expressing aphid inhibitors have also shown deterrent effect against aphids in feeding trials (Carrillo et al., 2011; Tran et al., 1997; Rahbe et al., 2003). Present study was first time carried out in Gujrat, Pakistan to determine the presence of unigene sequences in local aphid species which will help further in the incorporation of RNAi in aphids via transgenic plants and to produce resistance crop line by using this method. Systemic RNAi comprehend both cell internal signal/ environmental RNAi signal for its valid efficacy. This is an important step for their control in crop system, should be follow by their control measures.

PCR of unigene 28469 and 21789 was positive for all $M$. rosae, $R$. maidis, $S$. avenae, T. aurantii. These two unigene sequences were found to be novel and found to be present in 
Table 2. Primers used for PCR amplification of required gene region.

\begin{tabular}{|c|c|c|c|}
\hline Primer ID & Non-redundant protein database & Primers & $\mathrm{Tm}$ \\
\hline Unigene $23028(\mathrm{~F})$ & gi193695320 & 5-3' TTCAACTTCAGTCAACGGGATA & $56.3^{\circ} \mathrm{C}$ \\
\hline Unigene $23028(\mathrm{R})$ & & 5-3' TGTTGAACCCTTCTGACACG & $57.8^{\circ} \mathrm{C}$ \\
\hline Unigene $28469(\mathrm{~F})$ & No ortholog found & 5-3' AGCCAGGATGTTGGCTTAGA & $57.8^{\circ} \mathrm{C}$ \\
\hline Unigene $28469(\mathrm{R})$ & & 5-3' CTCATGTCAGCATTCGCACT & $57.8^{\circ} \mathrm{C}$ \\
\hline Unigene $8273(\mathrm{~F})$ & gi193716064 & 5-3' AGACGAACCAATTAGAGCAG & $55.7^{\circ} \mathrm{C}$ \\
\hline Unigene $8273(\mathrm{R})$ & & 5-3' GTTTCTTACAGCTCCACACC & $57.8^{\circ} \mathrm{C}$ \\
\hline Unigene $21789(\mathrm{~F})$ & No ortholog found & 5-3' CGGCAACAATTGACTCTAA & $53.2^{\circ} \mathrm{C}$ \\
\hline Unigene $21789(\mathrm{R})$ & & 5-3' GAAGTCACATGTTCGCACTA & $55.7^{\circ} \mathrm{C}$ \\
\hline Unigene $21088(\mathrm{~F})$ & gi254281286 & 5-3' TTGTTGAACCCTTCTGACA & $53.2^{\circ} \mathrm{C}$ \\
\hline Unigene $21088(\mathrm{R})$ & & 5-3' TGATTCAACTTCAGTCAACG & $53.7^{\circ} \mathrm{C}$ \\
\hline
\end{tabular}

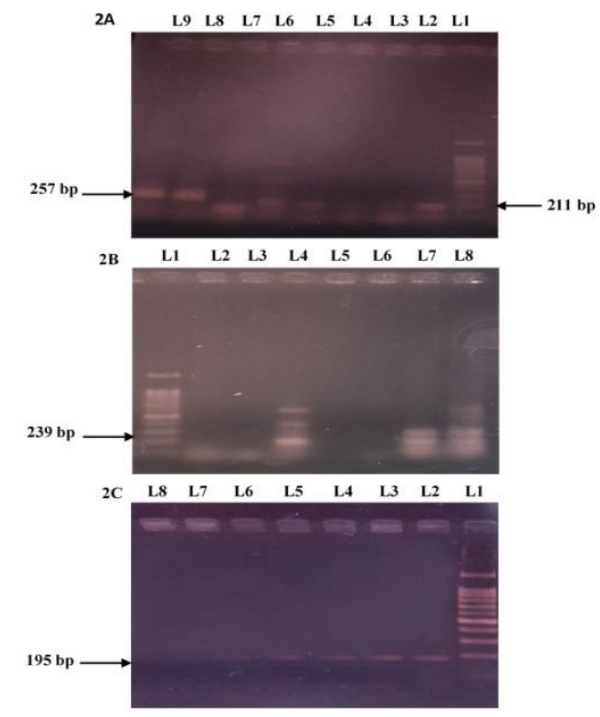

Fig 2. PCR of unigene 28469 and 21789. (A) PCR results were positive for all Macrosiphum rosae, Rhopalosiphum maidis, Sitobion avenae, Toxoptera aurantii reared on Rosa indica, Zea mays, Triticum aestivum, Chrysanthemum hibiscus, Solanum melongena, Abelmoschus esculentus. PCR of unigene 21789. L1. 100 bp Ladder L2: T. aurantii; L3: S. avenae; L4: R. maidis; L5: M. rosae. PCR of unigene 28469. L6: T. aurantii; L7: S. avenae; L8: R. maidis; L9: M. rosae. (B) PCR of unigene 8273: PCR results were found to be positive for $S$. avenae and M. rosae and negative for $R$. maidis and T. aurantii reared on R. indica, Z. mays, T. aestivum, C. hibiscus, S. melongena, A. esculentus. PCR of unigene 8273. L1. 100 bp Ladder; L2, 3, T. aurantii; L4: S. avenae; L5: R. maidis; L7, 8: M. rosae. (C) PCR of unigene 23028: PCR results were found to be positive for $R$. maidis, $S$. avenae and negative for $M$. rosae, and T. aurantii reared on R. indica, Z. mays, T. aestivum, C. hibiscus, S. melongena, A. esculentus. PCR of unigene $23028:$ L1. 100 bp Ladder; L7: M. rosae; L3 \& L4: R. maidis; L2: S. avenae; L8: T. aurantii.

Table 3. Presence of selected unigenes in local aphid species (Macrosiphum rosae, Rhopalosiphum maidis, Sitobion avenae, Toxoptera aurantii) reared on Rosa indica, Zea mays, Triticum aestivum, Chrysanthemum hibiscus, Solanum melongena, Abelmoschus esculentus, confirmed by RTPCR analysis.

\begin{tabular}{|c|c|c|c|c|c|}
\hline Unigenes & Annotations & M. rosae & R. maidis & S. avenae & T. aurantii \\
\hline 21789 & No orthologs identified & Present & Present & Present & Present \\
\hline 28469 & No orthologs identified & Present & Present & Present & Present \\
\hline 21088 & $\begin{array}{l}\text { Cytochrome c oxidase subunit VIIc } \\
\text { precursor (Acyrthosiphon pisum). }\end{array}$ & Present & Absent & Present & Present \\
\hline 23028 & Similar to zinc finger protein (A. pisum) & Absent & Present & Present & Absent \\
\hline 8273 & Cuticular proteins (A. pisum) & Absent & Present & Present & Absent \\
\hline
\end{tabular}

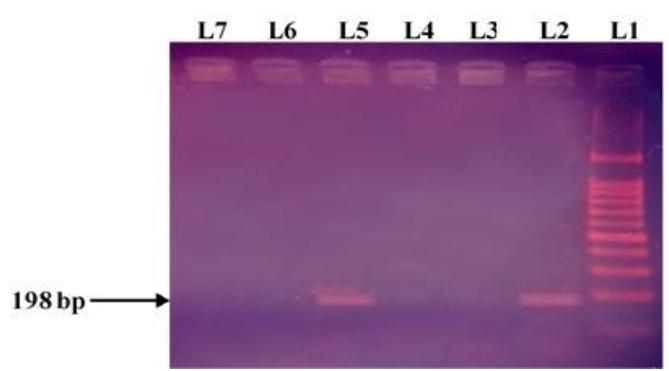

Fig 3. PCR of unigene 21088. PCR was found to be positive for M. rosae, S. avenae, T. aurantii and negative for $R$. maidis reared on R. indica, Z. mays, T. aestivum, C. hibiscus, S. melongena, A. esculentus. PCR of unigene 21088. L1. 100 bp Ladder; L2: S. avenae; L4, L6: R. maidis; L5: T. aurantii. 
all four aphids and had not the possibility to interfere with the wheat genome as well so could be important for broad resistance against grain aphids. Very small amount of dsRNA $(7.5 \mathrm{ng} / \mu \mathrm{l})$ as compared to previous data was found to be efficient for RNAi mediated silencing using these selected unigenes. So, these unigenes also favor minimal risk of nonspecific target but also maintain the low efficacy of lethal dose. $4 \mathrm{~d}$ later, the mortality levels of aphids fed with dsRNAs of C002 and unigenes 21088, 21789, 23028, 28469 and 29698 were between $60 \%$ and $90 \%$ after correction. This low dose effectiveness not only maintain the minimal risk of non-specific effects but also facilitate the application of plant-mediated RNAi silencing of these target genes for aphid control in agricultural practice. dsRNA could be taken by digestive system and was not localized to the midgut and temporally limited, could spread to the whole body tissues in grain aphid, then lead to a down-regulation/knock out of the target gene expression and finally to the development retarding and/or death of grain aphid. Number increases after feeding.

PCR of unigene 21088 was found to be positive for $M$. rosae, $S$. avenae, $T$. aurantii and negative for $R$. maidis. It encodes for cytochrome $c$ oxidase (CO-1) subunit VIIc precursor of (Acyrthosiphon pisum) and its expression reduced significantly reduced to half after feeding on artificial diet with this protein as RNAi target. CO-1 is used as bar coding gene for elucidation of cryptic aphid species of order Hemiptera (Rebijith et al., 2013). CO-I gene sequence as DNA barcoding is highly reported as effective tool for species identification (Foottit et al., 2008; Glover et al., 2010; Lee et al., 2010). In addition, CO-I may be suitably employed to elucidate the prevalence of biotypes and for the discovery of new species within the Aphididae (Shufran et al., 2000). PCR of unigene 23028 was found to be positive for $R$. maidis, S. avenae and negative for $M$. rosae, and T. aurantii. Unigene was zinc finger protein (Acyrthosiphon pisum) expression reduced drastically upon eating on artificial diet with RNAI target. Zinc finger protein form one of the largest group of proteins in small grain aphids (Nicholson et al., 2015). Zinc finger protein is reported as defense protein in plants and insects in response to grain aphids (Gupta et al., 2012; Guan et al., 2015).

PCR of unigene 8273 was found to be positive for $S$. avenae and $M$. rosae and negative for $R$. maidis and $T$. aurantii. Cuticular protein (CPs) decreases after feeding on artificial diet with this protein as RNAi target. CPs include non-structural and structural proteins. CPs Include RR-1 isolated from soft or flexible cuticles, and RR-2 proteins are more often associated with hard cuticles (Willis et al., 2005). It had been reported that cuticular protein is associated with seasonal variation and help the aphids to withstand the harsh conditions (Gallot et al., 2010). Synthesis of cuticular proteins is linked with the tyrosine synthesis occurred in early embryonic stages of pea aphid and is major precursor for cuticle maturation (Rabatel et al., 2013). Silva et al. (2012) reported culticular protein along with other enzymes related to energy metabolism, detoxifying enzymes, proteins of extracellular transport, and peptidases as defense mechanisms in response to insecticide in M. persicae.

All the unigenes were found to be present in S. avenae as this unigenes were selected from the study of $S$. avenae on wheat so unigenes are similarly expressed in local wheat aphids.

RNAi had been used as useful generic tool to produce insect resistant crops and was firstly introduced into the $C$. elegans to study the role of its individual gene (Fire et al., 1998). Success of RNAi experiments had been also observed in a number of lepidopteran species but variable rates of RNAi dependent knockdown had been observed (Price and Gatehouse, 2008; Terenius et al., 2011). Some genes used for dsRNA targets represents high mortality while others failed to be silenced. Secondly, vulnerability of novel targets to RNAi shows considerable variation in model species (Price and Gatehouse, 2008). Some proved to be completely recalcitrant to suppression as in neuronal expressed genes in C. elegans (Kennedy et al., 2004). Thirdly, risk of inadvertent cross-species silencing could be vital biosafety concern in RNAi mediated aphid resistance. Highly insect-specific genes with no good match to sequences in donor plants for engineering should be selected. Dosage of RNAi target is another important factor for targeted gene silencing. High variation subsists among different lepidopteran species, due to their sensitivity to systemic RNAi at adjustable levels. As, its not true that beyond optimal concentration results will be more efficient for silencing (Pitino et al., 2011; Shakesby et al., 2009; Terenius et al., 2011). Aphid injected with $5 \mathrm{nl}$ C002 SiRNA $(10 \mu \mathrm{g} / \mu \mathrm{l})$ led to knockdown of C002 gene and even lower doses observed in other cases (Mutti et al., 2006). In one of related study silencing of $\mathrm{C} 002$ gene and a gutspecific gene Rack-1 in peach aphid resulted in the knock down of these two genes by up to $60 \%$ after feeding on transgenic tobacco and Arabidopsis plants, with affected aphids producing less progeny (Shakesby et al., 2009).

Unigenes selected for the study were found to be friendly for wheat, diet containing them resulted in stunting \& death of aphids. Of these RNAi targets two unigenes 21789 and 28469 had no orthologs identified; so were novel in grain aphid and important RNAi target genes for aphid resistance in transgenic plants.

Systemic RNAi pathway is not found in most insect species except some lepidopteran species. As RNA pathways are highly conserved in aphids, so successful knockdown of target genes through RNAi was also observed in pea and peach aphid (Pitino et al., 2011; Shakesby et al., 2009). Few cases are reported for plant-mediated RNAi for aphid control. Silencing of $\mathrm{C002}$ gene and gut-specific gene Rack-1 in peach aphid resulting in $60 \%$ mortality after feeding on transgenic tobacco and Arabidopsis plants (Pitino et al., 2011).

We have found the expression of the variable expression of these unigenes in 4 local aphid species residing on variable host plants. Next target is to transcribe an antisense RNA from vector by cloning these targeted sequences in reverse orientation so that antisense RNA produced instead of Sense RNA. Vectors will be designed to express different siRNA molecules. This retrovirus-based vector will have two complementary sequences about 20 nucleotides in length that form a stem, separated by a loop region. When the vector will transform in cell, the shRNA will transcribed from these sequences and activates gene silencing. Transformation of model plant (tobacco) and cereals and vegetables will be done in future. Insect Bioassay will follow this. Aphids fed on transgenic cereals and vegetables with these RNAi targets will result in mortality of aphids along with down regulation of targeted sequences.

\section{Materials and Methods}

\section{Collection of explants}

Aphids are very host specific \& plants sampled were $R$. indica, Z. mays, T. aestivum, C. hibiscus, S. melongena and A. esculentus (Table 01). Sampling was done from the different regions of district Gujrat from young branches of 
plants with the help of very fine forceps. Samples were dislodged from the leaves or stems by using paintbrush. Some of aphids were stored in $70 \%$ alcohol and other were reared on wheat plants grown in pots at room temperature. Aphids were collected on their respective host plants. Aphid species were identified by Dr. Sumeira Afsheen (Associate Professor) Department of Zoology, University of Gujrat. We have found 4 different species of plants from their respective host. Compared with the entire region of Pakistan, the study area was very small, despite this, 4 different species were recorded (Table 1, Fig 1).

\section{DNA extraction}

M. rosae, $R$. maidis, S. avenae, T. aurantii reared on $R$. indica, Z. mays, T. aestivum, C. hibiscus, S. melongena, A. esculentus were grinded with liquid nitrogen in clean mortar and pestle (after Black et al., 1992) or was purified using three phenol, chloroform DNA extraction methods (Sambrook et al., 1989; Milligan, 1992; De Barro et al., 1995). Samples were stored at $4^{\circ} \mathrm{C}$ prior to use. Confirmation of DNA was done by gel electrophoresis (Fig S1A).

\section{Primer designing}

Sequence of five unigenes provided by Zhang et al. (2013) were used to design relatively suitable length of PCR primers using primer 3 online software (version 0.4.0; Rozen and Skaletsky, 2000).

\section{PCR reaction}

Conformation of the desire sequences in extracted DNA from all species was done by running PCR reaction. 5 primers were used that are basically the unigene sequenced and are proved as successful target for RNAi in aphids (Table 2). Set of PCR reaction was run with an initial denaturation step for $4 \mathrm{~min}\left(95^{\circ} \mathrm{C}\right)$, followed by 40 cycles of denaturation step for 30 seconds $\left(95^{\circ} \mathrm{C}\right)$, annealing temperature (as describe in Table 2) for $1.5 \mathrm{~min}$ and extension $\left(72^{\circ} \mathrm{C}\right)$ for $30 \mathrm{sec}$, and a final extension cycle of $7 \mathrm{~min}\left(72^{\circ} \mathrm{C}\right)$. The amplified PCR products were analyzed by agarose gel electrophoresis.

\section{Conformation of amplification}

Gel electrophoresis (1\% agarose gel) was conducted to confirm the PCR amplification. PCR amplified product $(2 \mu \mathrm{L})$ along with $4 \mu \mathrm{L} 6 \mathrm{X}$ loading dye was loaded on the gel while $100 \mathrm{bp}$ (Sigma Aldrich) ladder was being loaded $(2 \mu \mathrm{L})$ on a separate well.

\section{Aphid dissection}

M. rosae, $R$. maidis, S. avenae, T. aurantii reared on $R$. indica, Z. mays, T. aestivum, C. hibiscus, S. melongena, A. esculentus were harvested and sorted into different growth phases. Adult's aphids were dissected under a binocular microscope and their gut region was separated for RNA extraction. Dissected guts were kept on ice until adequate number had been collected and then stored at $-20^{\circ} \mathrm{C}$. Total RNA was isolated from both, dissected and whole aphids. The aphids used were adults for RNA extraction.
RNA extraction, primer designing and unigene gene acquisition

Aphids total RNA will be isolated using TRIZOL Reagent (Qiagen, USA) and RNA will be converted into cDNA using cDNA synthesis kit (Invitrogen, USA). cDNA was PCR amplified with unigene-specific primers. Confirmation of the desirable sequences in extracted cDNA from all species will be done by running PCR reaction with five set of primers under specific conditions.

\section{PCR analysis}

$20 \mathrm{ul}$ PCR reaction was made containing 1.5 of the template cDNA, 2ul Taq buffer, 1ul $\mathrm{MgCl}_{2}, 0.5 \mathrm{ul}$ dNTP mixture, 0.5 ul of each forward and reverse primer, 1ul Taq polymerase and $13 \mathrm{ul}$ of nanopure water. PCR reactions were run with an initial denaturation step for $4 \min \left(95^{\circ} \mathrm{C}\right)$, followed by 40 cycles of denaturation step for 30 seconds $\left(95^{\circ} \mathrm{C}\right)$, annealing temperature ( as describe in table ) for $1.5 \mathrm{~min}$ and extension $\left(72^{\circ} \mathrm{C}\right.$ ) for $30 \mathrm{sec}$, and a final extension cycle of $7 \mathrm{~min}$ $\left(72^{\circ} \mathrm{C}\right)$. The amplified PCR products were analyzed by agarose gel electrophoresis.

\section{Conclusion}

ds RNA designed against insect target genes gave protection against pests through RNAi, and open the way for a new generation of insect-resistant crops (Price and Gatehouse, 2008). Based on this observation 5 major exotic unigenes explored via transcriptomic profiling of wheat aphids were selected (Zhang et al., 2013). These unigenes were confirmed in our local aphid strains such as $M$. rosae, $R$. maidis, $S$. avenae, T. aurantii) feeding on $C$. sinensis, $R$. indica, $S$. melongen, Z. mays and T. aestivum. Application of RNAi to aphids is somehow constrains due to vulnerability of novel targets to RNAi show considerable variation in target species. Unigenes selected were found to be friendly for wheat and by feeding on diet containing them resulted in stunting and death of aphids. Risk of inadvertent cross-species silencing could be vital biosafety concern in RNAi mediated aphid resistance. Insect-specific genes were selected with no good match to sequences in donor plants for engineering. Of these five RNAi targets, two unigenes 21789 and 28469 had no orthologs identified. These unigenes are novel in grain aphid, and important RNAi target genes for aphid resistance in transgenic cereals and vegetable plants. The unigenes favor minimal risk of non-specific target but also maintain the low efficacy of lethal dose. These unigenes will be used for production of transgenic plant with RNAi vector. CO-I gene find out was reported as DNA barcoding will be used for further species identification. CPs and zing finger proteins were other defense proteins identified to be important for the aphid knockdown.

\section{Acknowledgement}

I would like to acknowledge Dr. Ramzan Khan for his help in English correction and improvement.

\section{References}

Altpeter F, Diaz I, Mcauslane H, Gaddour K, Carbonero P, Vasil IK (1999) Increased insect resistance in transgenic wheat stably expressing trypsin inhibitor CMe. Mol Breed. 5:53-63. 
Aslam M, Razaq M, Ahmad F, Faheem M, Akhter W (2004) Population of Aphid (Schizaphis graminum R.) on different varieties/lines of wheat (Triticum aestivum L.). Int J Agri Biol. 6(6):974-977.

Bhatia V, Bhattacharya R, Uniyal PL, Singh R, Niranjan RS (2012) Host generated siRNAs attenuate expression of serine protease gene in Myzus persicae. PLoS one 7(10):e46343. doi:10.1371/journal.pone.0046343

Bhatia V, Uniyal PL, Bhattacharya RC (2011) Aphid resistance in Brassica crops: challenges, biotechnological progress and emerging possibilities. Biotechnol Adv. 29:879-888.

Black WC, DuTeau NM, Puterka GJ, Nechols JR, Pettorini JM (1992) Use of random amplifed polymorphic DNA polymerase chain raction (RAPD-PCR) to detect DNA polymorphisms in aphids (Homoptera: Aphididae). Bull Ent Res. 82:151-159.

Blackman RL, Eastop VF (2000) Aphids on the World's Crops. John Wiley \& Sons, Chichester, England.

Blackman RL, Eastop VF (2006) Aphids on the world's herbaceous plants and shrubs. ISBN: 978-0-471-48973-3. John Wiley \& Sons, Chichester, England 1460pp.

Bruce TJA, Aradottir G, Smart LE, Martin JL, Caulfield JC, Doherty A, Sparks CA, Woodcock CM, Birkett MA, Napier JA, Jones HD, Pickett JA (2015) The first crop plant genetically engineered to release an insect pheromone for defence. Sci Rep. 5:11183. doi: 10.1038/srep11183.

Carrillo L, Martinez M, Alvarez-Alfageme F, Castanera P, Smagghe G, Diaz I, Ortego F (2011) A barley cysteineproteinase inhibitor reduces the performance of two aphid species in artificial diets and transgenic Arabidopsis plants. Transgenic Res. 20(2):305-319.

De Barro PJ, Sherratt TN, Brookes CP, David O, Maclean N (1995) Spatial and temporal variation in British field populations of the grain aphid Sitobion avenae (F.) (Hemiptera: Aphididae) studied using RAPD-PCR. Proc R Soc Lond. B 262:321-327.

Dedryver CA, Le Ralec A, Fabre F (2010) The conflicting relationships between aphids and men: A review of aphid damage and control strategies. CR Biol. 333:539-553.

Faheem M, Sajjad A, Shafique R.M (2015) Balanced use of fertilizers can reduce aphid infestation and impove yield in wheat crop. Asian J Agri Biol. 3(1):50-55.

Fire A, Xu SQ, Montgomery MK, Kostas SA, Driver SE, and Mello CC (1998) Potent and specific genetic interference by double-stranded RNA in Caenorhabditis elegans. Nature 391:806-811. doi:10.1038/35888.

Foottit RG, Maw HEL, von Dohlen CD, Hebert PDN (2008) Species identification of aphids (Insecta: Hemiptera: Aphididae) through DNA barcodes. Mol Ecol Resour. 8:1189-1201.

Gallot A, Rispe C, Leterme N, Gauthier J-P, Possamai SJ, Tagu D (2010) Cuticular proteins and seasonal photoperiodism in aphids. Insect Biochem Mol Biol. 40:235e240.

Giovanini MP, Saltzmann KD, Puthoff DP, Gonzalo M, Ohm HW, Williams CE (2007) A novel wheat gene encoding a putative chitin-binding lectin is associated with resistance against Hessian fly. Mol Plant Pathol. 8:69-82.

Glover RH, Collins DW, Walsh K, Boonham N (2010) Assessment of loci for DNA barcoding in the genus Thrips (Thysanopter a: Thripidae). Mol Ecol Resour. 10:51-59.

Guan W, Ferry N, Edwards MG, Bell HA, Othman H, Gatehouse JA, Gatehouse AMR (2015) Proteomic analysis shows that stress response proteins are significantly upregulated in resistant diploid wheat (Triticum monococcum) in response to attack by the grain aphid (Sitobion avenae). Mol Breed. 35:57.

Gupta SK, Rai AK, Kanwar SS, Sharma TR (2012) Comparative analysis of zinc finger proteins involved in plant disease resistance. PLoS ONE 7(8):e42578. doi:10.1371/journal.pone.0042578.

Hajibabaei M, Janzen DH, Burns JM, Hallwachs W, Hebert PD (2006) DNA barcodes distinguish species of tropical Lepidoptera. Proc Natl Acad Sci USA. 103:968-971.

Hamid H (1983) Natural balance of graminicolous aphids in Pakistan. Survey of populations.

Agronomie EDP Sci. 3(7):665-673

Hossain MA, Maiti MK, Basu A, Sen S, Ghosh AK (2006) Transgenic expression of onion leaf lectin gene in Indian mustard offers protection against aphid colonization. Crop Sci. 46:2022-2032.

Huvenne H, Smagghe G (2010) Mechanisms of dsRNA uptake in insects and potential of RNAi for pest control: a review. J Insect Physiol. 56:227-235.

Irshad M (2001) Aphids and their biological control in Pakistan. Pak J Bio Sci. 4(5):537-541.

Jose AM, Hunter CP (2007) Transport of sequence-specific RNA interference information between cells. Ann Rev Genet. 41:305-330.

Kennedy S, Wang D, Ruvkun G (2004) A conserved siRNAdegrading RNase negatively regulates RNA interference in C. elegans. Nature 427:645-649.

Khan AM, Khan AA, Afzal M, Iqbal MS (2012) Wheat Crop Yield Losses Caused by the Aphids Infestation. J Biofertil Biopestic. 3:122. doi:10.4172/2155-6202.1000122.

Kumar M, Gupta GP, Rajam MV (2009) Silencing of acetylcholinesterase gene of Helicoverpa armigera by siRNA affects larval growth and its life cycle. J Insect Physiol. 55:273-278.

Lee W, Kim H, Lim J, Choi H, Kim Y, Ji J, Foottit RG, Lee S (2010) Barcoding aphids (Hemiptera: Aphididae) of the Korean Peninsula: updating the global data set. Mol Ecol Resour. 11:1-6.

Li X, Han B, Xu M, Han L, Zhao Y, Liu Z, Dong $\mathrm{H}$, and Zhang C (2014) Plant growth enhancement and associated physiological responses are coregulated by ethylene and gibberellin in response to harpin protein Hpa1. Planta 239(4):831-846.

Mani M (1987) Role of parasitoids and predators in the biological control of fruit and vegetable corp pests in India. Proc. seminar cum workshop. Biol Control Crop Pests and Weeds Tech. Doc. No. 19:108-119.

Mao YB, Cai WJ, Wang JW, Hong GJ, Tao XY, Wang LJ, Huang YP, Chen XY (2007) Silencing a cotton bollworw P450 monooxygenase gene by plant-mediated RNAi impairs larval tolerance of gossypol. Nature Biotechnol. 25:1307-1313.

Meister G, Tuschl T (2004) Mechanism of gene silencing by double-stranded RNA. Nature 431:343-349.

Milligan BG (1992) Plant DNA isolation. In Molecular genetic analysis of populations (ed. A. R. Hoelzel), pp. 5988. Oxford: IRL Press.

Muhammad W, Nasir M, Abbas SK, Irshad M, Abbas MW, Nawaz A, Atta-ur-Rehman (2013) Resistance pattern against aphid (Diuraphis noxia) in different wheat varieties /lines at district Layyah. Acad J Entomol. 6 (3):116-120.

Mutti NS, Park Y, Reese JC, Reeck GR (2006) RNAi knockdown of a salivary transcript leading to lethality in the pea aphid Acyrthosiphon pisum. J Insect Sci. 6:38:1-7.

Nicholson SJ, Nickerson ML, Dean M, Song Y, Hoyt PR, Rhee H, Kim C, Puterka GJ (2015) The genome of 
Diuraphis noxia, a global aphid pest of small grains. BMC Genomics 16:429

Oerke EC, Dehne HW, Schonbeck F, Weber A (1994) Crop production and crop protection-estimated losses in major food and cash crops. Amsterdam: Elsevier Science. 808 pp.

Pitino M, Hogenhout SA (2013) Aphid protein effectors promote aphid colonization in a plant species-specific manner. Mol Plant Microbe Interact. 26:130-139.

Pitino M, Coleman AD, Maffei ME, Ridout CJ, Hogenhout SA (2011) Silencing of aphid genes by dsRNA feeding from plants. PLoS One 6:e25709.

Possamai JS, Trionnaire GL, Bonhomme J, Christophides GK, Rispe C, Tagu D (2007) Gene knockdown by RNAi in the pea aphid Acyrthosiphon pisum. BMC Biotechnol. 7:63.

Price DR, Gatehouse JA (2008) RNAi-mediated crop protection against insects. Trends Biotechnol. 26(7):393400.

Quratulain, Aslam M, Rafique MK, Ahmad MA, Mahmood R (2015) Population dynamics of rose aphid Macrosiphum rosae L. on different cultivars of Rosa indica L. in Pakistan. Pak J Agric Res. 28(3):281-286.

Rabatel A, Febvay G, Gaget K, Duport G, Baa-Puyoulet P, Sapountzis P, Bendridi N, Rey M, Rahbe Y, Charles H, Calevro F, Colella S (2013) Tyrosine pathway regulation is host-mediated in the pea aphid symbiosis during late embryonic and early larval development. BMC Genomics 14:235.

Rahbe Y, Deraison C, Bonade-Bottino M, Girard C, Nardon C, Jouanin L (2003) Effects of the cysteine protease inhibitor oryzacystatin (OC-I) on different aphids and reduced performance of Myzus persicae on OC-I expressing transgenic oilseed rape. Plant Sci. 164(4):441450.

Rebijith KB, Asokan R, Krishna Kumar NK , Krishna V, Chaitanya BN, Ramamurthy VV (2013) DNA barcoding and elucidation of cryptic aphid species (Hemiptera: Aphididae) in India. Bull Entomol Res. 103:601-610.

Repellin A, Baga M, Jauhar PP, Chibbar RN (2001) Genetic enrichment of cereal crops via alien gene transfer: New challenges. Plant Cell Tissue Organ Cult. 64:159-183.

Richard S, Gibbs RA, Weinstock GM, Brown SJ, Denell R, Beeman RW, Gibbs R, Bucher G, Friedrich M, Grimmelikhuijzen CJP (2008) The genome of the model beetle and pest Tribolium castaneum. Nature 452:949- 955.

Rozen S, Skaletsky HJ (2000) Primer3 on the www for general users and for biologist programmers. In: Krawetz S, Misener S (eds) Bioinformatics methods and protocols: methods in molecular biology. Humana Press, Totowa, pp 365-386.

Sambrook J, Fritsch EF., Maniatis T (1989) Molecular cloning: a laboratory Manual, 2nd ed. New York: Cold Spring Harbour Laboratory Press.

Shahzad MW, Razaq M, Hussain A, Yaseen M, Afzal M, Mehmood MK (2013) Yield and yield components of wheat (Triticum aestivum $\mathrm{L}$. affected by aphid feeding and sowing time at Multan, Pakistan. Pak J Bot. 45(6):20052011.

Shakesby AJ, Wallace IS, Isaacs HV, Pritchard J, Roberts DM, Douglas AE (2009) A water-specific aquaporin involved in aphid osmoregulation. Insect Biochem Mol Biol. 39:1-10.

Shufran KA, Burd JD, Anstead JA, Lushai G (2000) Mitochondrial DNA sequence divergence among greenbug (Homoptera: Aphididae) biotypes: evidence for host adapted races. Insect Mol Biol. 9:179-184.
Silva AX, Jander G, Samaniego H, Ramsey JS, Figueroa CC (2012) Insecticide resistance mechanisms in the green peach aphid Myzus persicae (Hemiptera: Aphididae) I: A transcriptomic survey. PLoS One 7(6):e36366.

Stoger E, Williams S, Christou P, Down RE, Gatehouse JA (1999) Expression of the insecticidal lectin from snowdrop (Galanthus nivalis agglutinin; GNA) in transgenic wheat plants: effects on predation by the grain aphid Sitobion avenae. Mol Breed. 5:65-73.

Terenius O, Papanicolaou A, Garbutt JS, Eleftherianos I, Huvenne H, Kanginakudru S, Albrechtsen M, An C, Aymeric JL, Barthel A (2011) RNA interference in Lepidoptera: an overview of successful and unsuccessful studies and implications for experimental design. J Insect Physiol. 57:231-245.

Tian H, Peng H, Yao Q, Chen H, Xie Q, Tang B, Zhang W (2009) Developmental control of a lepidopteran pest Spodoptera exigua by ingestion of bacteria expressing dsRNA of a non-midgut gene. PLoS One 4(7): e6225.

Tomoyasu Y, Miller SC, Tomita S, Schoppmeier M, Grossmann D, Bucher G (2008) Exploring systemic RNA interference in insects: a genome-wide survey for RNAi genes in Tribolium. Genome Biol. 9(1). doi:10.1186/gb2008-9-1-r10.

Tran P, Cheesbrough TM, Keickhefer RW (1997) Plant proteinase inhibitors are potential anti-cereal aphid compounds. J Econ Entomol. 90(6):1672-1677.

Turner CT, Davy MW, MacDiarmid RM, Plummer KM, Birch NP, Newcomb RD (2006) RNA interference in the light brown apple moth, Epiphyas postvittana (Walker) induced by double-stranded RNA feeding. Insect Mol Biol. 15(3):383-391.

Usta C (2013) Microorganisms in Biological Pest Control-A Review (Bacterial Toxin Application and Effect of Environmental Factors). Current Progress in Biological Research (Chapter 13). (http://creativecommons.org/licenses/by/3.0).

Wains MS, Jamil MW, Ali MA, Hussain M, Anwar J (2014) Germplasm screening and incorporation of aphid resistance in bread wheat (Triticum aestivum L.). J Anim Plant Sci. 23(3):919-925.

Wang Y, Huang X-L, Qiao G-X (2013) Comparative analysis of mitochondrial genomes of five aphid species (Hemiptera: Aphididae) and phylogenetic implications. PLoS One 8 (10): e77511.

Wang ZY, Sun XF, Wang F, Tang KX, Zhang JR (2005) Enhanced resistance of snowdrop lectin (Galanthus nivalis L. agglutinin)-expressing maize to asian corn borer (Ostrinia furnacalis Guenee). $\mathrm{J}$ Integr Plant Biol. 47(7):873-880.

Whyard S, Singh AD, Wong S (2009) Ingested doublestranded RNAs can act as species-specific insecticides. Insect Biochem Mol Biol. 39:824-832.

Willis JH, Iconomidou VA, Smith RF, Hamodrakos SJ (2005) Cuticular proteins. In: Gilbert L, Iatrou K, Gill S (Eds.) Comprehensive Molecular Insect Science, vol. 4. Elsevier, Oxford, pp: 79e109.

Xu L, Duan X, Lv Y, Zhang X, Nie Z, Xie C, Ni Z, Liang R (2014) Silencing of an aphid carboxylesterase gene by use of plant mediated RNAi impairs Sitobion avenae tolerance of Phoxim insecticides. Transgenic Res. 23:389-396.

Yu XD, Pickett J, Ma Y, Bruce T, Napier J, Jones HD, Xia LQ (2012) Metabolic engineering of plant-derived (E)- $\beta$ farnesene synthase genes for a novel type of aphid-resistant genetically-modified crop plants. J Integr Plant Biol. 54:282-299. 
Zha W, Peng X, Chen R, Du B, Zhu L, He G (2011) Knockdown of midgut genes by dsRNA-transgenic plantmediated RNA interference in the hemipteran insect Nilaparvata lugens. PLoS One 6:e20504.

Zhang M, Zhou Y, Wang H, Jones HD, Gao Q, Wang D, Ma Y, Xia L (2013) Identifying potential RNAi targets in grain aphid (Sitobion avenae F.) based on transcriptome profiling of its alimentary canal after feeding on wheat plants. BMC Genomics. 14:560
Zhang YJ, Jiang YY, Feng XD, Xia B, Zeng J, Liu Y (2009) Occurring trends of major crop pests in national significances in 2009. China Plant Prot. 29:33-36.

Zhao YY, Liu F, Yang G, You MS (2011) PsOr1, a potential target for RNA interference-based pest management. Insect Mol Biol. 20(1):97-10. 